\title{
Transient Down-Regulation of Androgen Receptor Messenger Ribonucleic Acid (mRNA) Expression in Sertoli Cells by Follicle-Stimulating Hormone Is Followed by Up-Regulation of Androgen Receptor mRNA and Protein*
}

\author{
LEEN J. BLOK, JOS W. HOOGERBRUGGE, AXEL P.N. THEMMEN $\dagger$, WILLY M. BAARENDS, \\ MIRIAM POST, AND J. ANTON GROOTEGOED \\ Department of Endocrinology and Reproduction, Medical Faculty, Erasmus University, Rotterdam, \\ The Netherlands
}

\begin{abstract}
Cooperative actions of FSH and androgens on initiation, maintenance, and restoration of spermatogenesis have been described. In the present experiments the regulatory effects of FSH on androgen receptor (AR) gene expression in Sertoli cells were studied.

In immature rats injection of FSH $(1 \mu \mathrm{g} / \mathrm{g} \mathrm{BW}$, ip) resulted in a rapid down-regulation of testicular AR mRNA expression $(4 \mathrm{~h})$, followed by recovery to the control level $(10 \mathrm{~h})$. Using cultured immature Sertoli cells, a similar transient effect on AR mRNA expression was observed after the addition of FSH $(500 \mathrm{ng} / \mathrm{ml})$ or $(\mathrm{Bu})_{2}$ cAMP $(0.5$ $\mathrm{mM}$ ). Cycloheximide treatment of the cells did not prevent the rapid FSH-induced down-regulation of AR mRNA expression, indicating that de novo protein synthesis is not required for this effect. Further-
\end{abstract}

more, using a transcriptional run-on assay, no marked decrease in the rate of $A R$ gene transcription was found upon treatment of the cultured Sertoli cells with FSH for 2 or $4 \mathrm{~h}$. This demonstrates that the short term effect of FSH on AR mRNA expression reflects a change in mRNA stability. The AR protein level was not markedly affected by the transient decrease in AR mRNA expression.

When immature Sertoli cells were incubated with FSH for longer time periods (24-72 h), both AR mRNA and protein expression were increased. In Sertoli cells isolated from 15-day-old rats, this increase was higher (mRNA, 2- to 3-fold; protein, 2-fold) than in Sertoli cells isolated from 25 -day-old animals.

The results indicate that FSH plays a complex role in the regulation of AR expression in immature rat Sertoli cells. (Endocrinology 131: 1343-1349, 1992)
$\mathrm{F}^{\mathrm{s}}$ $\mathrm{H}, \mathrm{AN}$ important hormonal regulator of spermatogenesis, exerts its effects on germ cell development through regulation of Sertoli cell activities (1-3). The addition of FSH to cultured Sertoli cells from immature rats results in various changes in the synthesis and secretion of a number of proteins (4). In FSH action, the cAMP signal transduction pathway plays a central role. The ability of $\mathrm{FSH}$ to induce changes in intracellular calcium levels, however, has also been documented (5-8). The available information indicates that the involvement of the phosphatidylinositol pathway in FSH action is not very pronounced $(9,10)$.

Testosterone, the other major hormonal regulator of spermatogenesis, is produced by Leydig cells and exerts actions on peritubular myoid cells and Sertoli cells (11). Germ cells do not express the androgen receptor (AR) $(12,13)$. It is likely, therefore, that the effects of testosterone on spermatogenesis are mediated by peritubular myoid cells and Sertoli cells.

\section{Received February 5, 1992}

Address all correspondence and requests for reprints to: L. J. Blok, Department of Endocrinology and Reproduction, Medical Faculty, Erasmus University, Rotterdam, P.O. Box 1738, 3000 DR Rotterdam, The Netherlands.

* This work was supported by the Dutch Science Foundation (N.W.O.) through GB-MW (Medical Sciences).

† Recipient of a fellowship from the Royal Academy of Sciences (K.N.A.W. fellowprogram).
The AR is an intracellular protein, which, upon androgen binding, is transformed to a DNA-binding form (14). This transformed receptor can regulate the expression of androgen-dependent genes $(15,16)$.

Substitution of either FSH or testosterone to hypophysectomized rats can maintain spermatogenesis qualitatively, at approximately $70 \%$ of the normal level. Only when both hormones are administered together can quantitatively normal spermatogenesis be maintained (17). From these and many other experiments $(1,18-20)$, it has become clear that the actions of FSH and testosterone on spermatogenesis show a cooperative effect.

In long term stimulation experiments of cultured Sertoli cells from immature rats in the presence of FSH ( 3 days), the amounts of androgen receptor mRNA and protein were elevated $(21-23)$. In the present study the effects of FSH on expression of the AR gene were examined in more detail, with an emphasis on short term effects. Experiments were conducted using intact immature rats and cultured Sertoli cells isolated from these animals. Northern blotting, nuclear run-on transcription experiments, and specific ligand binding assays were performed to analyze AR gene expression.

\section{Materials and Methods}

\section{Isolation of Sertoli cells}

Sertoli cells from 15-, 21-, or 25-day-old rats were isolated using a method described by Themmen et al. (24). The resulting cell population 
was allowed to attach, at a density of $10^{6}$ cells $/ \mathrm{cm}^{2}$, in either 24-well plates (for estimation of $\left[{ }^{3} \mathrm{H}\right] \mathrm{R} 1881$ binding) or $75-\mathrm{cm}^{2}$ culture flasks (for RNA extraction), for 2 days. The culture conditions were Eagle's Minimum Essential Medium supplemented with antibiotics and nonessential amino acids (MEM) at $37 \mathrm{C}$ in air containing $5 \% \mathrm{CO}_{2}$ in the presence of $1 \%$ fetal calf serum. Subsequently, the cells were subjected to a hypotonic shock ( $10 \%$ MEM in $\mathrm{H}_{2} \mathrm{O}$ for $2 \mathrm{~min}$ ) to remove remaining germ cells $(25,26)$. The cells were allowed to recover for $24 \mathrm{~h}$ in MEM containing $0.1 \%(\mathrm{wt} / \mathrm{vol}) \mathrm{BSA}$. The cells were then cultured, in the presence or absence of hormones, in MEM containing $0.1 \%$ BSA. The experiments were repeated four or five times using different cell preparations. Within one experiment all incubations were terminated at the same time (control and hormone-treated). The hormone treatment protocols are described in Results.

Alkaline phosphatase staining was used to evaluate the purity of the cell preparations (27). When 15 -day-old rats were used, $0.5 \%$ contamination with peritubular myoid cells was observed; when 21- or 25-dayold rats were used, the contamination was less than $0.1 \%$ (during and at the end of the incubations).

The ligand binding assay (22) and the RNA extraction and hybridization (28) were carried out as described by Blok $e t$ al.

Analysis of variance and Tukey's test were used to determine significant differences $(P<0.01)$. Data are expressed as the mean \pm SD.

\section{Nuclear mRNA elongation (run-on)}

Nuclei were isolated from immature Sertoli cells that had been cultured in the presence of FSH $(500 \mathrm{ng} / \mathrm{ml})$ for 0,2 , or $4 \mathrm{~h}$. The whole procedure was carried out at $4 \mathrm{C}$. The incubation was terminated by placing the culture flasks on ice. The cells were washed twice with PBS and once with Tris buffer ( $10 \mathrm{~mm}$ Tris, $10 \mathrm{~mm} \mathrm{NaCl}$, and $3 \mathrm{mM} \mathrm{MgCl}_{2}$, $\mathrm{pH}$ 7.4). Subsequently, the cells were incubated in lysis buffer [0.5\% ( $\mathrm{vol} / \mathrm{vol}$ ) Nonidet P-40 (BDH Chemicals Ltd., Poole, England), $10 \mathrm{~mm}$ Tris, $10 \mathrm{~mm} \mathrm{NaCl}$, and $3 \mathrm{~mm} \mathrm{MgCl}, \mathrm{pH} 7.4]$ for $20 \mathrm{~min}$. The cells were detached from the plastic by dynamic shaking. The nuclei and remaining whole cells were centrifuged $(500 \times g ; 5 \mathrm{~min})$, and the pellet was washed in lysis buffer. The pellet was resuspended in $5 \mathrm{ml}$ sucrose buffer $\mathrm{A}$ [0.32 $\mathrm{m}$ sucrose (BDH), $3 \mathrm{~mm} \mathrm{CaCl}, 2 \mathrm{~mm} \mathrm{Mg}$ acetate, $0.1 \mathrm{~mm}$ EDTA, $10 \mathrm{~mm}$ Tris, and $5 \mathrm{~mm}$ dithiothreitol (Sigma, St. Louis, MO), $\mathrm{pH} \mathrm{8.0]}$ containing $0.1 \%$ Triton $\mathrm{X}-100(\mathrm{BDH})$ to lyse the remaining cell membranes. Different protease inhibitors [0.6 mm bacitracin (Janssen Chimica, Beerse, Belgium) and $0.6 \mathrm{~mm}$ phenylmethylsulfonylfluoride] were added. The suspension was kept on ice for $5 \mathrm{~min}$ and homogenized by 30 strokes with a Dounce homogenizer (pestle type B, Wheaton Scientific, Millville, NJ). The resulting homogenate was mixed with $11 \mathrm{ml}$ sucrose buffer B $[2.05 \mathrm{M}$ sucrose (BDH), $5.0 \mathrm{~mm} \mathrm{Mg}$ acetate, $0.1 \mathrm{~mm}$ EDTA, and $10 \mathrm{~mm}$ Tris, $\mathrm{pH} \mathrm{8.0]}$. The mixture, with a final sucrose concentration of approximately $1.4 \mathrm{M}$, was applied to a 4-ml cushion of sucrose buffer $B$ and centrifuged using a Beckman SW $40 \mathrm{Ti}$ rotor (Beckman, Geneva, Switzerland; $48.000 \times g ; 45 \mathrm{~min} ; 0 \mathrm{C}$ ). This method, using nonionic detergents to lyse the cells and sucrose gradient centrifugation to recover the nuclei, resulted in a very clean nuclear pellet which could be used in the run-on assay. The nuclei were resuspended in $100 \mu \mathrm{l}$ storage buffer ( $25 \%$ glycerol, $5 \mathrm{~mm} \mathrm{Mg}$ acetate, $0.1 \mathrm{~mm}$ EDTA,

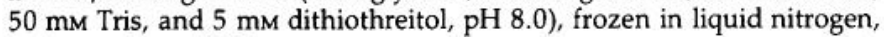
and stored at $-70 \mathrm{C}$.

Nuclear elongation was performed essentially as described by Marzluff and Huang (29) and Ausubel et al. (30). In short, $25 \times 10^{6}$ nuclei were incubated with ATP, CTP, UTP, and $\left[\alpha{ }^{-32} \mathrm{P}\right] \mathrm{GTP}(3000 \mathrm{Ci} / \mathrm{mmol}$; Amersham, Aylesbury, Buckinghamshire, United Kingdom). Sephadex G-50 columns were used to separate labeled pre-mRNA from unincorporated NTPs. Labeled RNA $\left(3 \times 10^{6} \mathrm{cpm}\right)$ was added to $2 \mathrm{ml}$ hybridization mixture. Plasmid DNA was bound to Biotrans nylon blotting filter (ICN Biomedicals, Inc., Irvine, CA) using a dot blot apparatus (Schleicher and Schuell, Dassel, Germany; $10 \mu \mathrm{g}$ plasmid DNA/dot). The plasmids used were pTZ (pTZig, Pharmacia LKB Biotechnology, Uppsala, Sweden) as a control for background hybridization, pTZ-AR-910 (31) and pTZ$0.3 \mathrm{~A}(32)$ human AR cDNA, pRK-FSHR-NH2 and pRK-FSHR-COOH rat FSH receptor $\mathrm{CDNA}(33), \alpha 7 / \mathrm{pUC} 18$ rat inhibin cDNA (28), and pUC9-Act hamster actin cDNA. The hybridization was allowed to proceed for $65 \mathrm{~h}$ at $55 \mathrm{C}$. The blots were washed at $55 \mathrm{C}$ using $1 \times \mathrm{SSC}$ ( $150 \mathrm{~mm} \mathrm{NaCL}$ and $15 \mathrm{~mm} \mathrm{Na}$-citrate) for $15 \mathrm{~min}$ in case of PTZ, AR, and FSH receptor run-on assays. Inhibin and actin run-on hybridizations were washed with $0.2 \times$ SSC containing $0.25 \%$ (wt/vol) sodium dodecyl sulfate for $45 \mathrm{~min}$ at $55 \mathrm{C}$. Blots were sealed in plastic and autoradiographed. The run-on experiments were repeated three times, using three different Sertoli cell isolations.

\section{Experimental animals}

Wistar rats (substrain R-1 Amsterdam) were housed, six per cage, in a controlled environment with a light cycle of $12 \mathrm{~h}$ of light and $12 \mathrm{~h}$ of darkness and received rat diet ad libitum. Ten animals were injected ip with FSH [1 $\mu \mathrm{g}$ ovine FSH (FSH-S16)/g BW] dissolved in $0.9 \%$ (wt/vol) $\mathrm{NaCl}$ containing $0.1 \%$ (wt/vol) BSA (fraction V; Sigma). Four control animals received only $0.9 \%$ (wt/vol) $\mathrm{NaCl}$ containing $0.1 \%$ BSA. The animals were killed $2-10 \mathrm{~h}$ later for testicular RNA isolation. Other untreated animals were killed for Sertoli cell isolation.

All animal experimentation described in this manuscript was conducted in accord with the highest standards of human animal care, as outlined in Guidelines for the Care and Use of Experimental Animals.

\section{Results}

\section{Short term effects of FSH}

Intact immature rats (21-day-old) were injected with FSH (1 $\mu \mathrm{g}$ ovine FSH-S16/g BW, ip) and killed $0,2,4,6,8$, and $10 \mathrm{~h}$ after injection to analyze the amount of AR mRNA present in the testis (Fig. 1). Within $4 \mathrm{~h}$ after the injection of $\mathrm{FSH}$, the amount of androgen receptor mRNA in the testis was decreased to a very low level $(10 \pm 6 \%$ of the control; mean \pm SD of three animals). At later time points after FSH injection, the amount of AR mRNA returned to approximately the control level (Fig. 1). All Northern blots were hybridized to a hamster actin cDNA probe to verify the amount of total mRNA that was applied to the lanes on the gel.

ARs in the testis are located in different somatic cell types, including Sertoli cells. To investigate the effect of FSH on purified Sertoli cells, these cells were isolated from 21-day-

\section{$\begin{array}{llllll}\text { Con } & 2 & 4 & 6 & 8 & 10\end{array}$}

\section{ARmRNA}

\section{Actinm RNA}

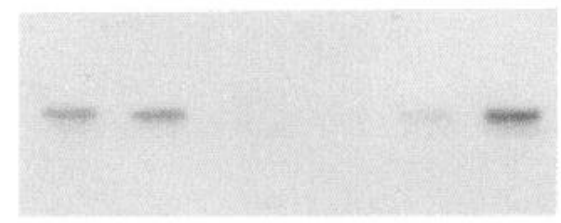

FIG. 1. Effect of FSH on testicular AR mRNA expression. The 21. day-old rats were injected (ip) with $1 \mu \mathrm{g}$ ovine FSH S16/g BW and killed $2,4,6,8$, or $10 \mathrm{~h}$ later. Con, Control (saline injected and killed 4 $\mathrm{h}$ later). For Northern analysis, $20 \mu \mathrm{g}$ total RNA, isolated from total testis, were applied per lane and analyzed using a human AR cDNA probe and a hamster actin cDNA probe. Actin was used to verify the amounts of mRNA that were applied per lane on the gel. 
old rats and cultured in the presence of $500 \mathrm{ng} / \mathrm{ml}$ ovine FSH S16, which is known to be a maximally stimulating dose (34). It was observed that during the first $5 \mathrm{~h}$ after FSH administration, the level of AR mRNA decreased to a barely detectable value $(15 \pm 4 \%$ of the control; mean \pm SD of five experiments; Fig. 2). This low level was rapidly restored to the control level between 5-8 $\mathrm{h}$ of culture in the continuous presence of FSH (Fig. 2). Similar results were obtained using Sertoli cells isolated from 15- and 25-day-old rats (not shown).

A dose-response curve was produced for $\mathrm{FSH}$-induced $\mathrm{AR}$ mRNA down-regulation (Fig. 3). The $\mathrm{ED}_{50}$ was approximately $10 \mathrm{ng} / \mathrm{ml}$. For comparison, the $\mathrm{ED}_{50}$ values for several other nonrelated effects of FSH on cultured Sertoli cells, including stimulation of cAMP production, c-fos expression, glycolysis, and inhibin $\alpha$-subunit expression (34-36), were approximately the same.

The cAMP transduction pathway plays an important role in FSH action. Therefore, immature Sertoli cells were also cultured in the presence of $(\mathrm{Bu})_{2}$ CAMP (dbcAMP) or forskolin. It was found that both dbcAMP (Fig. 4) and forskolin (not shown) mimicked the effect of FSH.

The incorporation of $\mathrm{L}-\left[1-{ }^{14} \mathrm{C}\right]$ leucine in cultured Sertoli cells treated with cycloheximide $(50 \mu \mathrm{g} / \mathrm{ml})$ was reduced by $98 \%$ within $30 \mathrm{~min}$. As shown in Fig. 5, this cycloheximide treatment stimulated the level of AR mRNA $1.7 \pm 0.4$-fold (mean \pm SD of four experiments). When FSH was added to the cell cultures for $4 \mathrm{~h}$, starting $30 \mathrm{~min}$ after cycloheximide administration, the amount of AR mRNA was decreased. The magnitude of this decrease was comparable to that of the decrease after FSH treatment without cycloheximide $(0.7$ $\mathrm{U}$ on the y-axis; Fig. 5). It can be concluded that de novo

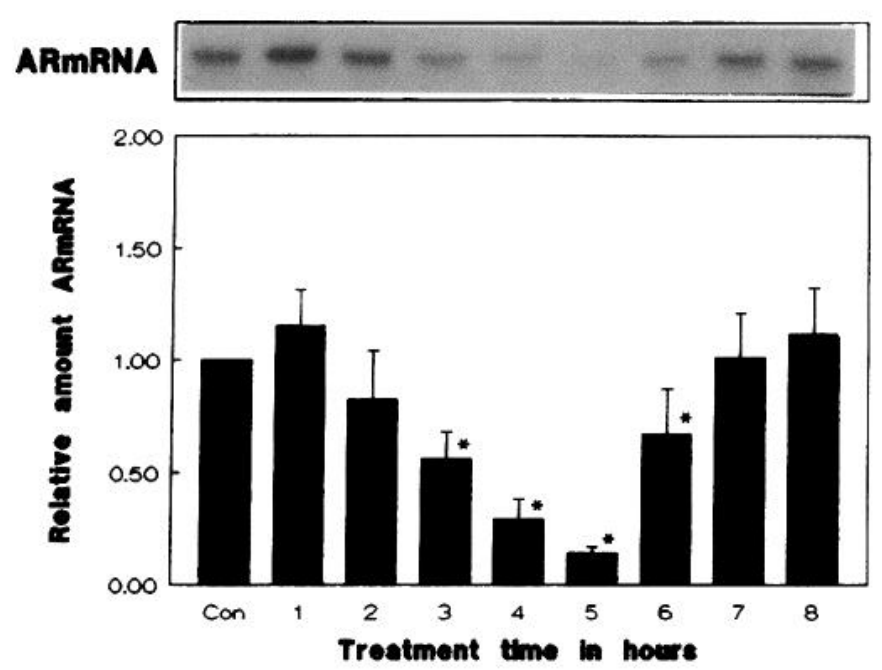

FIG. 2. Effect of FSH on AR mRNA expression in cultured Sertoli cells. Sertoli cells from 21-day-old rats were cultured for 1, 2, 3, 4, 5, 6, 7 , and $8 \mathrm{~h}$ in the presence of ovine FSH S16 $(500 \mathrm{ng} / \mathrm{ml})$. Con, Control. For Northern analysis, $20 \mu \mathrm{g}$ total RNA were applied per lane and analyzed using a human AR cDNA probe. The different lanes were scanned, and the amount of AR mRNA was determined relative to that in the control lane (1.00). The experiment was repeated five times (the bars represent the mean $\pm S D$, whereas the autoradiograph is a representative sample from a single experiment). ${ }^{*}$, Significantly different from the control $(P<0.01)$.

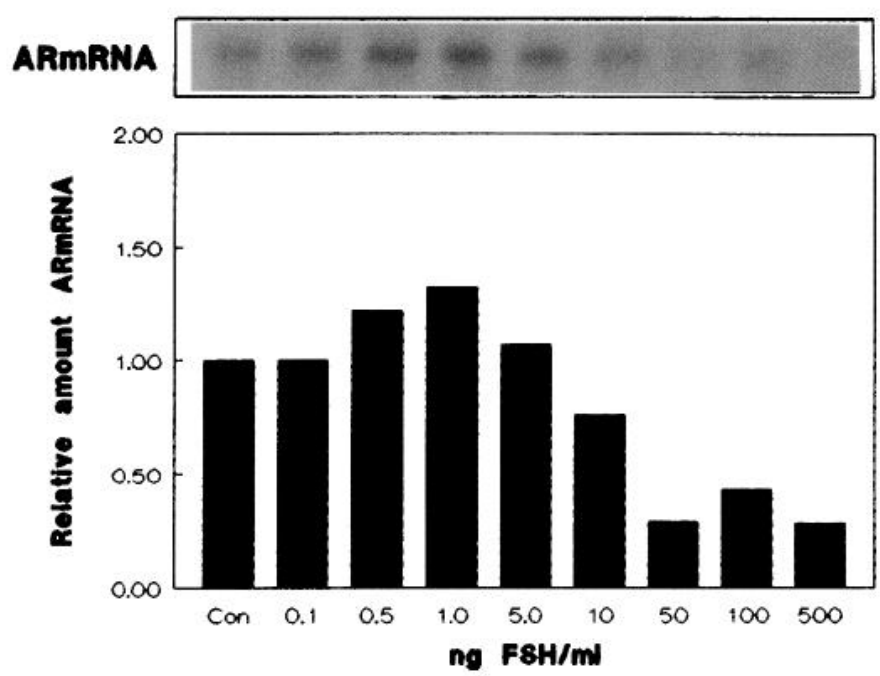

FIG. 3. FSH dose-response curve for FSH-regulated AR mRNA expression. Sertoli cells from 21-day-old rats were cultured for $4 \mathrm{~h}$ in the presence of $0.05,0.1,0.5,1,5,10,50,100$, and $500 \mathrm{ng} / \mathrm{ml}$ ovine FSH S16. Con, Control. For Northern analysis, $20 \mu \mathrm{g}$ total RNA were applied per lane and analyzed using a human AR cDNA probe. The different lanes were scanned, and the amount of AR mRNA was determined relative to that in the control lane (1.00).

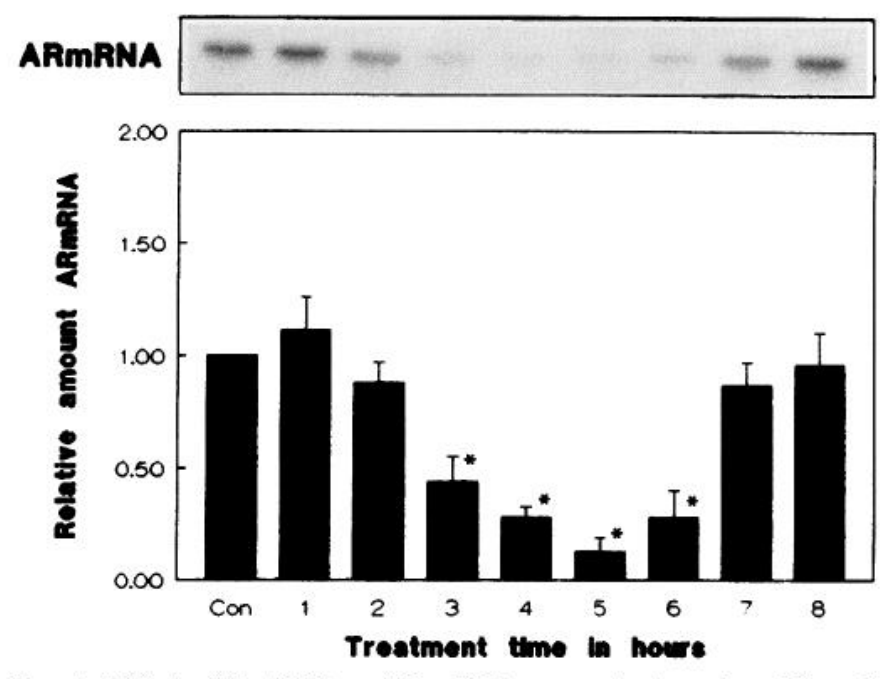

FIG. 4. Effect of dbcAMP on AR mRNA expression in cultured Sertoli cells. Sertoli cells from 21-day-old rats were cultured for $1,2,3,4,5,6$, 7 , and $8 \mathrm{~h}$ in the presence of dbcAMP $(0.5 \mathrm{~mm})$. Con, Control. For Northern analysis, $20 \mu \mathrm{g}$ total RNA were applied per lane and analyzed using a human AR cDNA probe. The different lanes were scanned, and the amount of AR mRNA was determined relative to that in the control lane (1.00). The experiment was repeated four times (the bars represent the mean $\pm \mathrm{SD}$, whereas the autoradiograph is a representative sample from a single experiment). *, Significantly different from the control $(P<0.01)$.

protein synthesis is not needed for FSH-induced downregulation of $A R$ mRNA.

Down-regulation of mRNA expression, in general, can result from a lowered transcription rate and/or decreased mRNA stability. To study AR gene transcription, nuclear RNA elongation experiments (run-on analysis) were performed. Double stranded probes, used to capture the labeled mRNA, can also detect antisense mRNAs. The presence of 

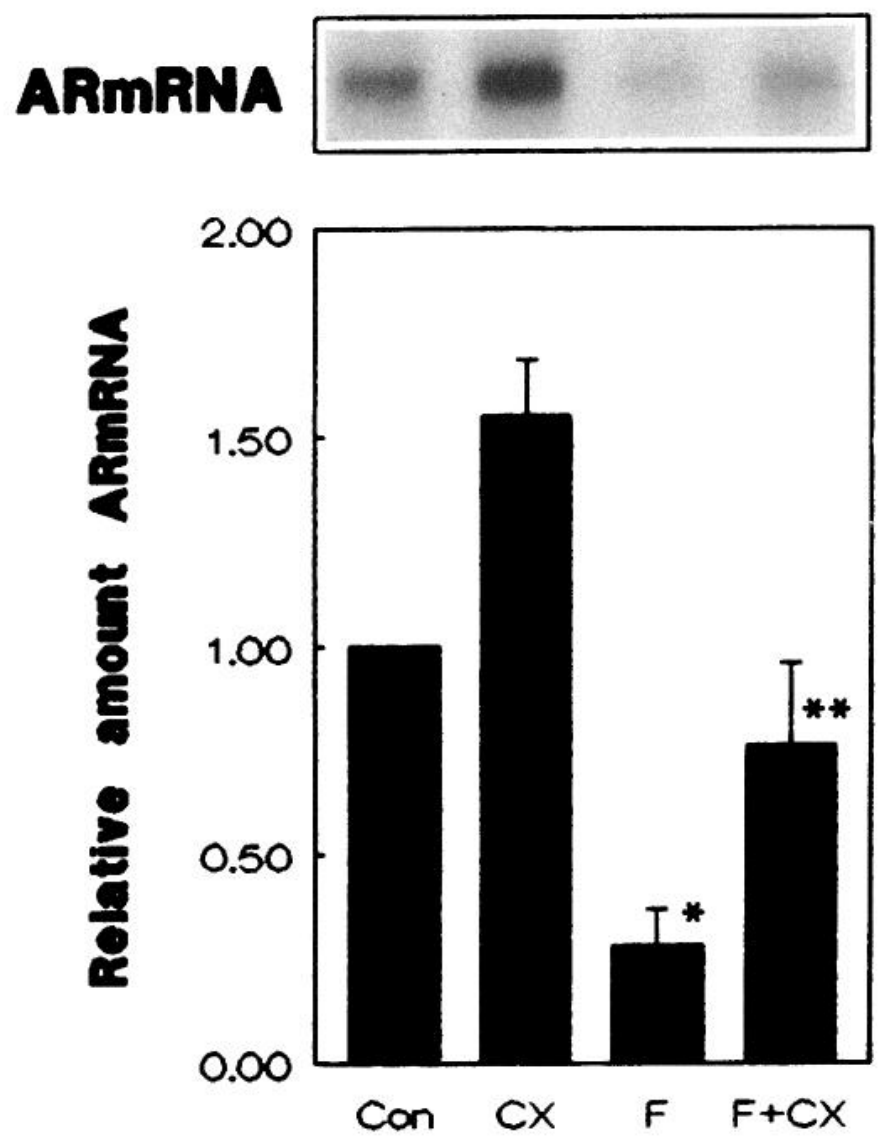

FIG. 5. FSH regulation of AR mRNA expression in the presence of cycloheximide. Sertoli cells from 21-day-old rats were cultured for $4 \mathrm{~h}$ in the presence of cycloheximide $(50 \mu \mathrm{g} / \mathrm{ml})$ and or ovine FSH S16 $(500 \mathrm{ng} / \mathrm{ml})$. Con, Control; CX, treated for $4.5 \mathrm{~h}$ with cycloheximide; FSH, treated for $4 \mathrm{~h}$ with FSH; F + CX, 30 min after cycloheximide addition, FSH was added to the cells for $4 \mathrm{~h}$. For Northern analysis, 20 $\mu \mathrm{g}$ total RNA were applied per lane and analyzed using a human AR cDNA probe. The different lanes were scanned, and the amount of AR mRNA was determined relative to that in the control lane (1.00). The experiment was repeated four times (the bars represent the mean \pm $\mathrm{SD}$, whereas the autoradiograph is a representative sample from a single experiment). ${ }^{*}$, Significantly different from the control $(P<0.01) .{ }^{* *}$, Significantly different from cycloheximide-treated groups $(P<0.01)$.

antisense transcripts, however, is not likely, because only one distinct 10-kilobase (kb) AR mRNA transcript was detected in cultured Sertoli cells and testicular tissue. Recently, Faber et al. (32) gave a detailed characterization of possible AR gene transcripts. Using several probes that were located at different parts of the cDNA, they found $10-$ and $7-\mathrm{kb}$ transcripts. The $7-\mathrm{kb}$ transcript represents an alternative splice product that is not found in testicular cells and was detected using a $0.5-\mathrm{kb} E c o \mathrm{RI} / E c o \mathrm{RI}$ human $\mathrm{AR} \mathrm{cDNA}$ probe. In the present experiments the same probe was used. A 4$\mathrm{kb}$ AR gene transcript has been described, but this appeared to be a breakdown product from the $10-\mathrm{kb}$ AR mRNA (28).

Using a nuclear run-on assay, no marked change in the transcription rate of the AR gene was observed after incubation of Sertoli cells for 2-4 $\mathrm{h}$ in the presence of FSH (Fig. 6). Klaij et al. (37) showed that stimulation of expression of inhibin $\alpha$-subunit mRNA by FSH in Sertoli cells takes place within $2 \mathrm{~h}$. This effect is thought to involve a direct effect of

\section{Con 24}

pTZ

$\mathbf{A} \mathbf{R}$

FSH-R

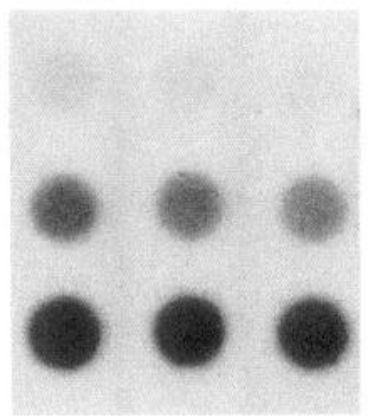

$\operatorname{Inh} \alpha$

Act

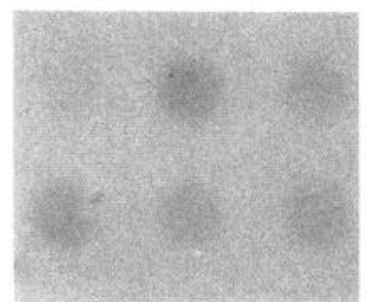

FIG. 6. Quantitation of the initiation of AR gene transcription in cultured Sertoli cells. Sertoli cells isolated from 21-day-old rats were cultured in the presence of ovine FSH S16 $(500 \mathrm{ng} / \mathrm{ml})$ for 2 or $4 \mathrm{~h}$. Nuclei were isolated, and transcriptional run-on experiments were performed, as described in Materials and Methods. Con, Control; FSH$\mathrm{R}, \mathrm{FSH}$ receptor; Inh $\alpha$, inhibin $\alpha$-subunit; Act, actin. pTZ was used as a control for background hybridization. The experiment was repeated three times with essentially the same results. The autoradiograph shows the results from one experiment.

FSH on gene transcription (37); the promoter region contains a cAMP response element (38). In the present run-on experiments, inhibin $\alpha$-subunit gene transcription was elevated by FSH within $2 \mathrm{~h}$ (Fig. 6). This represents a positive control. No induction or suppression of actin gene transcription was observed (Fig. 6).

The amount of AR present in Sertoli cells was measured by specific ligand $\left(\left[{ }^{3} \mathrm{H}\right] \mathrm{R} 1881\right)$ binding assay. It was observed that the pronounced down-regulation of AR mRNA did not result in a marked decrease in AR protein (Fig. 7).

\section{Long term effects of FSH}

The short term effects described herein are seemingly in contradiction to a stimulatory effect of FSH on AR expression in cultured Sertoli cells, described previously (21-23). These previous observations, however, concern long term experiments. In the present series of experiments we incubated Sertoli cells with FSH for longer time periods (24-72 h). At the end of these incubations, a net increase in the AR mRNA level was observed (Fig. 8). This long term effect of FSH on AR mRNA expression in Sertoli cells was more pronounced in Sertoli cells from 15-day-old rats than in those from 25day-old rats.

Measurement of the total binding of $\left[{ }^{3} \mathrm{H}\right] \mathrm{R} 1881$ to Sertoli cells from 15-day-old rats incubated for 24-72 h with FSH 


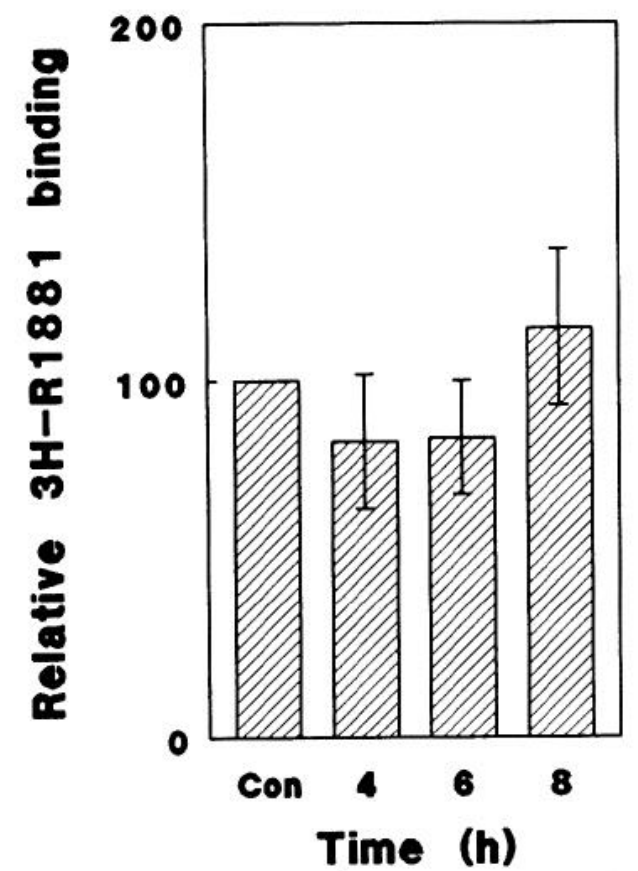

FIG. 7. Short term effect of FSH on $\left[{ }^{3} \mathrm{H}\right] \mathrm{R} 1881$ binding to Sertoli cells. The cells were isolated from 21-day-old rats and cultured in the presence of ovine FSH S16 (500 ng/ml) for 4,6 , and $8 \mathrm{~h}$. Con, Control. The experiment was repeated four times (the bars represent the mean $\pm \mathrm{SD}) .{ }^{*}$, Significantly different from the control $(P<0.01)$.
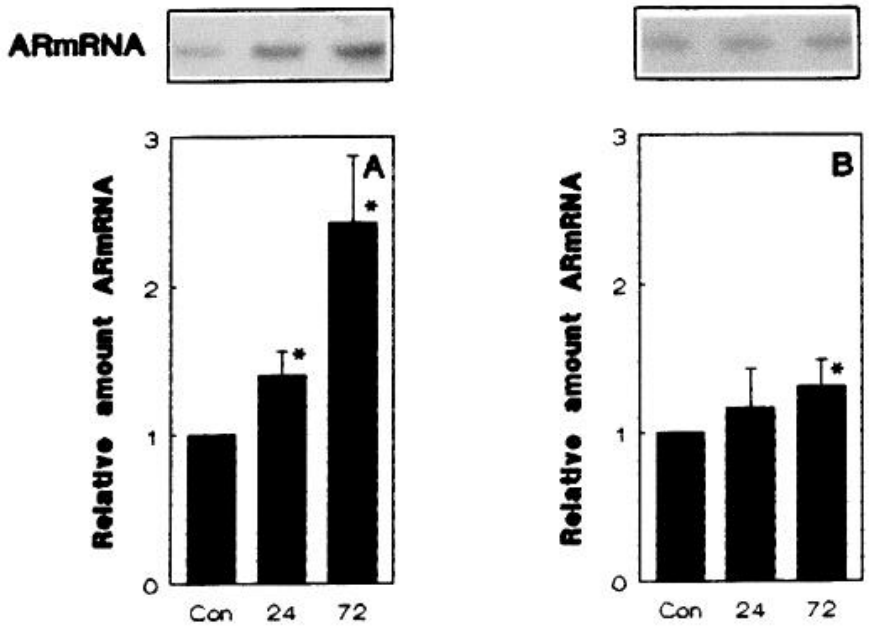

Time (h)

FIG. 8. Long term effect of FSH on AR mRNA expression. Sertoli cells from 15-day-old (A) and 25-day-old (B) rats were cultured for 24 and $72 \mathrm{~h}$ in the presence of ovine FSH S16 $(500 \mathrm{ng} / \mathrm{ml})$. Con, Control. For Northern analysis, $20 \mu \mathrm{g}$ total RNA were applied per lane and analyzed using a human AR cDNA probe. The different lanes were scanned, and the amount of AR mRNA was determined relative to that in the control lane (1.00). The experiment was repeated four times (the bars represent the mean $\pm \mathrm{SD}$, and the autoradiograph shows the results from one experiment). ${ }^{*}$, Significantly different from the control $(P<$ $0.01)$.

revealed FSH-induced up-regulation of ligand binding (1.8 \pm 0.2 -fold; mean \pm SD of four experiments), which was much less pronounced using Sertoli cells from 25-day-old rats (Fig. 9).

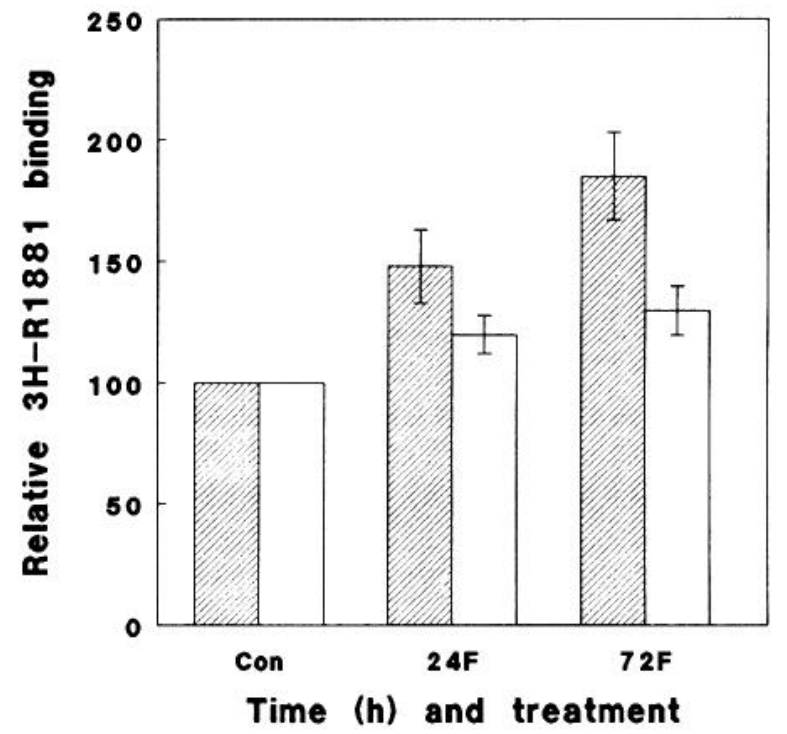

FIG. 9. Long term effect of FSH on $\left[{ }^{3} \mathrm{H}\right] \mathrm{R} 1881$ binding to Sertoli cells. The cells were isolated from 15 -day-old $(\mathbb{Z})$ and 25 -day-old $(\square)$ rats and cultured in the presence of ovine FSH S16 $(500 \mathrm{ng} / \mathrm{ml})$ for 24 and $72 \mathrm{~h}$. Con, Control. The experiment was repeated four times (the bars represent the mean $\pm \mathrm{SD})$. ${ }^{*}$, Significantly different from the control $(P<0.01)$.

Addition of testosterone, either alone or with $\mathrm{FSH}$, to the cultures did not significantly change the level of AR mRNA expression (not shown). However, the binding of $\left.{ }^{3} \mathrm{H}\right] \mathrm{R} 1881$ to cells incubated with testosterone was increased $3.2 \pm 0.6$ fold (mean \pm SD of three experiments; not shown). Furthermore, when FSH was added with testosterone to the Sertoli cell cultures, $\left[{ }^{3} \mathrm{H}\right] \mathrm{R} 1881$ binding was increased $4.1 \pm 0.7$-fold (mean \pm SD of three experiments; not shown).

\section{Discussion}

\section{Short term effects of FSH}

FSH administration (ip) to immature rats resulted in a rapid, but transient, decrease in AR mRNA expression in the testis. Apparently, the circulating FSH level is not a maximally stimulating dose (39). When highly purified immature Sertoli cells were used, a similar effect of FSH on AR mRNA expression was observed. In both situations, in vivo and in vitro, the amount of AR mRNA was decreased to a very low level within 4-6 h and then returned to the control level within several hours. The circulating FSH levels in vivo were not measured, but it can be assumed that these levels are very high shortly after FSH injection, but will return to the normal physiological range $10 \mathrm{~h}$ after FSH injection. To further investigate AR mRNA expression in the continuous presence of a defined dose of FSH, highly purified cultured Sertoli cells from immature rats were used.

The effect of FSH on cultured immature Sertoli cells involves rapid stimulation of the cellular cAMP level, followed by a decrease within a few hours. This decrease is caused by a desensitization process that involves receptor internalisation $(24,40)$, loss of adenylate cyclase activity (41), and 
increased phosphodiesterase activity $(42,43)$. In concordance with this, the effects of dbcAMP on Sertoli cells are usually much more persistent then the effects of FSH. This was also described for FSH-induced down-regulation of FSH receptor mRNA levels in cultured immature Sertoli cells (24), showing a transient effect of FSH, but a prolonged effect of dbcAMP. In the present experiments, however, the short term effect of $\mathrm{dbcAMP}$ on AR mRNA expression also was transient and virtually equivalent to the effect produced by FSH. This transient effect of dbcAMP is difficult to explain. Possibly, it involves activation of a second messenger system other than cAMP (e.g. a calcium-mediated response) (44).

The addition of cycloheximide to block protein synthesis resulted in increased AR mRNA expression in cultured Sertoli cells. Stabilization of distinct mRNAs is not an uncommon event after cycloheximide treatment, and several explanations have been suggested (45-47). FSH-induced downregulation of AR mRNA expression did occur in the presence of cycloheximide. This indicates that de novo protein synthesis is not required for this FSH effect. FSH action may result in activation or deactivation of preexisting proteins that are involved in the regulation of AR mRNA expression.

The results of the run-on experiments indicate that FSHinduced down-regulation of AR mRNA expression in Sertoli cells cannot be accounted for by a lower rate of gene transcription. It is possible that the stability of the AR mRNA is decreased upon FSH stimulation. Secondary structures in the untranslated regions of mRNAs may serve as binding sites for proteins that are involved in mRNA stability regulation (48). In future experiments we will study whether the large $5^{\prime}$ - and $3^{\prime}$-untranslated regions of AR mRNA may play a role in the regulation of its stability.

The amount of AR protein in cultured Sertoli cells, measured using a $\left[{ }^{3} \mathrm{H}\right] \mathrm{R} 1881$ binding assay, did not follow the short term FSH-induced diminution of AR mRNA expression. This can be explained when the half-life of the mRNA is much shorter than the half-life of the protein. Under FSHinduced down-regulation conditions, the AR mRNA showed a calculated half-life of approximately $1 \mathrm{~h}$, while the reported half-life for an unoccupied AR in the ductus deferens smooth muscle tumor cell line DDT 1 MF-2 is $3.1 \mathrm{~h} \mathrm{(49)}$

\section{Long term effects of FSH}

In Sertoli cells from 15-day-old rats, incubated for 3 days with FSH, AR mRNA expression was 2- to 3-fold increased. Using Sertoli cells from 25-day-old rats, only a small increase (<1.5-fold) in AR mRNA expression was observed.

The effect of age can be explained. Steinberger et al. (50) found that the amount of cAMP produced by cultured Sertoli cells upon FSH stimulation decreased with the age of the animals used for cell isolation. In their 4-day cultures of Sertoli cells isolated from 18-day-old rats, the FSH-induced cAMP production was 8 -fold higher than that in 4 -day cultures of Sertoli cells from 24-day-old rats.

The AR protein concentration ([ $\left.{ }^{3} \mathrm{H}\right] \mathrm{R} 1881$ binding) closely followed the FSH-induced long term changes in AR mRNA expression. This indicates that the long term action of FSH is mainly on AR mRNA expression, rather than on mRNA translation and/or receptor stability. The sensitivity of the nuclear run-on assay is not sufficient to detect the long term, relatively small changes in transcription rate. Therefore, $\mathrm{AR}$ promoter constructs (51), cloned in front of a reporter gene, are presently used by us to study whether FSH regulates AR gene transcription.

Incubation of Sertoli cells in the presence of testosterone demonstrated a marked posttranscriptional effect of testosterone on AR protein expression (specific ligand binding was increased 3-fold by testosterone, without an effect on AR mRNA expression). This observation is in agreement with our previous results using Sertoli cells (22) and results from Syms et al. (49), who reported increased stability of the AR when occupied with ligand in the ductus deferens smooth muscle tumor cell line DDT 1 MF-2.

In conclusion, marked effects of FSH on the regulation of AR expression in Sertoli cells were observed. Short term transient FSH-induced down-regulation of AR mRNA expression takes place in vivo as well as in vitro. However, this down-regulation in vitro, in cultured Sertoli cells, did not result in a short term decrease in androgen binding to the cells. Long term stimulation of cultured Sertoli cells with FSH resulted in elevated levels of both AR mRNA and protein. It is suggested that FSH plays an important role in regulating the AR concentration in Sertoli cells in the testis of immature rats.

\section{Acknowledgments}

The authors wish to thank the NIH (Bethesda, MD) for the ovine FSH S16, Drs. S. Shimasaki and N. Ling (Japan) for providing the inhibin cDNA, Drs. A. O. Brinkmann and J. Trapman (Rotterdam, The Netherlands) for providing the human androgen receptor CDNAs, and Dr. R. Sprengel (Heidelberg, Germany) for providing the rat FSH receptor cDNA plasmids.

\section{References}

1. Steinberger $\mathbf{E} 1971$ Hormonal control of mammalian spermatogenesis. Physiol Rev 51:1-22

2. Dorrington JH, Roller NF, Fritz IB 1975 Effects of follicle-stimulating hormone on cultures of Sertoli cell preparations. Mol Cell Endocrinol 3:57-70

3. Fritz IB 1978 Sites of action of androgens and follicle-stimulating hormone on cells of the seminiferous tubule. In: Litwack G (ed) Biochemical Actions of Hormones. Academic Press, New York, vol 5:249-281

4. Cheng CY, Mather JP, Byer AL, Bardin CW 1986 Identification of hormonally responsive proteins in primary Sertoli cell culture medium by anion-exchange high performance liquid chromatography. Endocrinology 118:480-488

5. Means AR, Dedman JR, Tash JS, Tindall DJ, van Sickle M, Welsh MJ 1980 Regulation of the testis Sertoli cell by follicle-stimulating hormone. Annu Rev Physiol 42:59-70

6. Grasso P, Reichert LE 1989 Follicle-stimulating hormone receptormediated uptake of ${ }^{45} \mathrm{Ca}^{++}$by proteoliposomes and cultured rat Sertoli cells: evidence for involvement of voltage-activated and voltage-independent calcium channels. Endocinology 125:3029 3036

7. Grasso P, Reichert LE 1990 Follicle-stimulating hormone receptormediated uptake of ${ }^{45} \mathrm{Ca}^{++}$by cultured rat Sertoli cells does not require activation of cholera toxin- or pertussis toxin-sensitive guanine nucleotide binding proteins or adenylate cyclase. Endocrinology 127:949-956 
8. Grasso P, Joseph MP, Reichert LE 1991 A new role for folliclestimulating hormone in the regulation of calcium flux in Sertoli cells: inhibition of $\mathrm{Na}^{+} / \mathrm{Ca}^{+}$exchange. Endocrinology 128:158-164

9. Quirk SM, Reichert LE 1988 Regulation of the phosphoinositide pathway in cultured Sertoli cells from immature rats: effects of follicle-stimulating hormone and fluoride. Endocrinology 123:230237

10. Monaco L, Adamo S, Conti M 1988 Follicle-stimulating hormone modulation of phosphoinositide turnover in the immature rat Sertoli cell in culture. Endocrinology 123:2032-2039

11. Skinner MK 1991 Cell-cell interactions in the testis. Endocr Rev 12:45-77

12. Grootegoed JA, Peters MJ, Mulder E, Rommerts FFG, van der Molen HJ 1977 Absence of a nuclear androgen receptor in isolated germinal cells of rat testis. Mol Cell Endocrinol 9:159-167

13. Anthony CT, Kovacs WJ, Skinner MK 1989 Analysis of the androgen receptor in isolated testicular cell types with a microassay that uses an affinity ligand. Endocrinology 125:2628-2635

14. Brinkmann AO, Lindh LM, Breedveld DI, Mulder E, van der Molen, HJ 1983 Cyproterone acetate prevents translocation of the androgen receptor in rat prostate. Mol Cell Endocrinol 32:117-129

15. Mainwaring WIP 1969 A soluble androgen receptor in the cytoplasm of rat prostate. I Endocrinol 45:531-541

16. Schrader WT, Birnbaumer ME, Hughes MR, Weigel NL, Grody WW, O'Malley BW 1981 Studies on the structure and function of the chicken progesterone receptor. In: Greep RD (ed) Recent Progress in Hormone Research. Academic Press, New York, vol 37:583633

17. Bartlett JMS, Weinbauer GF, Nieschlag E 1989 Differential effects of FSH and testosterone on the maintenance of spermatogenesis in the adult hypophysectomized rat. I Endocrinol 121:49-58

18. Clermont Y, Harvey SC 1967 Effects of hormones on spermatogenesis in the rat. In: Ciba Foundation Colloquia on Endocrinology. Churchill-Livingstone, London, vol 16:173-189

19. de Kretser DM, Catt EJ, Paulsen CA 1971 Studies on the in vitro testicular binding of iodinated luteinizing hormone in rats. Endocrinology 88:332-337

20. Russell LD, Alger LE, Nequin LG 1987 Hormonal control of pubertal spermatogenesis. Endocrinology 120:1615-1632

21. Verhoeven G, Cailleau J 1988 Follicle-stimulating hormone and androgens increase the concentration of the androgen receptor in Sertoli cells. Endocrinology 122:1541-1550

22. Blok LJ, Mackenbach P, Trapman J, Themmen APN, Brinkmann AD, Grootegoed JA 1989 Follicle-stimulating hormone regulates androgen receptor mRNA in Sertoli cells. Mol Cell Endocrinol 63:267-271

23. Sanborn BM, Caston LA, Chang C, Liao S, Speller R, Porter LD, Ku CY 1991 Regulation of androgen receptor mRNA in rat Sertoli and peritubular cells. Biol Reprod 45:634-641

24. Themmen APN, Blok LJ, Post M, Baarends WM, Hoogerbrugge JW, Parmentier M, Vassart G, Grootegoed, JA 1991 Follitropin receptor down-regulation involves a cAMP-dependent post-transcriptional decrease of receptor mRNA expression. Mol Cell Endocrinol 78:R7-R13

25. Galdieri M, Ziparo E, Palombi F, Russo MA, Stefanini M 1981 Pure Sertoli cell cultures: a new model for the study of somaticgerm cell interactions. J Androl 2:249-254

26. Oonk RB, Grootegoed JA 1987 Insulin-like growth factor-I (IGF-I) receptors on Sertoli cells from immature rats and age-dependent testicular binding of IGF-I and insulin. Mol Cell Endocrinol 49:5162

27. Palombi F, Pi Carlo C 1988 Alkaline phosphatase is a marker for myoid cells in cultures of rat peritubular and tubular tissue. Biol Reprod 39:1101-1109

28. Blok LJ, Bartlett JMS, Bolt-de Vries J, Themmen APN, Brinkmann AD, Weinbauer GF, Nieschlag E, Grootegoed JA 1992 Effect of testosterone deprivation on expression of the androgen receptor in rat prostate, epididymis and testis. Int J Androl 15:182-198

29. Marzluff WF, Huang RCC 1984 Transcription of RNA in isolated nuclei, In: Hames BD, Higgins SJ (eds) Transcription and Transla- tion, a Practical Approach. IRL Press, Oxford, pp 89-128

30. Ausubel FM, Brent R, Kingston RE, Moore DD, Seidman JG, Smith JA, Struhl K 1989 Current Protocols in Molecular Biology. Wiley and Sons, New York

31. Jenster G, van der Korput JAGM, van Vroonhoven C, van der Kwast TH, Trapman J, Brinkmann AO 1991 Domains of the human androgen receptor involved in steroid-binding, transcriptional activation and subcellular localization. Mol Endocrinol 5:1396-1404

32. Faber PWF, van Rooij HCJ, van der Korput JAGM, Baarends WM, Brinkmann AO, Grootegoed JA, Trapman J 1991 Characterisation of the human androgen receptor transcription unit. J Biol Chem 266:10743-10749

33. Sprengel R, Braun T, Nikolics K, Segaloff DL, Seeburg PH 1990 The testicular receptor for follicle-stimulating hormone: structure and functional expression of cloned cDNA. Mol Endocrinol 4:525530

34. Oonk RB, Grootegoed JA, van der Molen HJ 1985 Comparison of the effects of insulin and follitropin on glucose metabolism by Sertoli cells from immature rats. Mol Cell Endocrinol 42:39-48

35. Hall SH, Joseph DR, French FS, Conti M 1988 Follicle-stimulating hormone induces transient expression of the proto-oncogene c-fos in primary Sertoli cell cultures. Mol Endocrinol 2:55-61

36. Toebosch AMW, Robertson DM, Klaij IA, de Jong FH, Grootegoed JA 1989 Effects of FSH and testosterone on highly purified rat Sertoli cells: inhibin $\alpha$-subunit mRNA expression and inhibin secretion are enhanced by FSH but not by testosterone. J Endocrinol 122:757-762

37. Klaij IA, Toebosch AM, Themmen APN, Shimasaki S, de Jong FH, Grootegoed JA 1990 Regulation of inhibin $\alpha$ - and $\beta$-subunit mRNA levels in rat Sertoli cells. Mol Cell Endocrinol 68:45-52

38. Esch FS, Shimasaki S, Cooksey K, Mercado M, Mason AJ, Ying SY, Ueno N, Ling N 1987 Complementary deoxyribonucleic acid (cDNA) cloning and DNA sequence analysis of rat ovarian inhibins. Mol Endocrinol 1:388-396

39. Means AR, Hall PF 1967 Effect of FSH on protein biosynthesis in testes of the immature rat. Endocinology $81: 1151-1160$

40. O'Shaughnessy PJ 1980 FSH receptor autoregulation and cyclic AMP production in the immature rat testis. Biol Reprod 23:810-814

41. Verhoeven G 1980 Androgen receptor in cultured interstitial cells derived from immature rat testis. J Steroid Bioch 13:469-474

42. Conti M, Toscano MV, Geremia R, Stefanini M 1983 Folliclestimulating hormone regulates in vizo testicular phosphodiesterase. Mol Cell Endocrinol 29:79-89

43. Conti M, Geremia R, Adamo S, Stefanini M 1981 Regulation of Sertoli cell cyclic adenosine $3^{\prime}: 5^{\prime}$ monophosphate phosphodiesterase activity by follicle-stimulating hormone and dibutyryl cyclic AMP. Biochem Biophys Res Commun 98:1044-1050

44. Gorczynska E, Handelsman DJ 1991 The role of calcium in folliclestimulating hormone signal transduction in Sertoli cells. J Biol Chem 266:23739-23744

45. Shaw J, Meerovitch K, Bleackley RC, Paetkau V 1988 Mechanisms regulating the level of IL-2 mRNA in T lymphocytes. J Immunol 140:2243-2248

46. Gay DA, Sisodia SS, Cleveland DW 1989 Autoregulatory control of beta-tubulin mRNA stability is linked to translation elongation. Proc Natl Acad Sci USA 86:5763-5767

47. Dittman WA, Kumada T, Majerus PW 1989 Transcription of thrombomodulin mRNA in mouse hemangioma cells is increased by cycloheximide and thrombin. Proc Natl Acad Sci USA 86:71797182

48. Nielsen DA, Shapiro DJ 1990 Insights into hormonal control of messenger RNA stability. Mol Endocrinol 4:953-957

49. Syms AJ, Norris JS, Panko WB, Smith RG 1985 Mechanism of androgen receptor augmentation. J Biol Chem 260:455-461

50. Steinberger A, Hintz M, Heindel JJ 1978 Changes in cyclic AMP responses to FSH in isolated rat Sertoli cells during sexual maturation. Biol Reprod 19:566-572

51. Baarends WM, Themmen APN, Blok LJ, Mackenbach P, Brinkmann AO, Meijer D, Faber PW, Trapman J, Grootegoed JA 1990 The rat androgen receptor gene promoter. Mol Cell Endocrinol $74: 75-84$ 